\title{
Prevalence of Bacterial Vaginosis among Married Women in Kalar District, Iraqi Kurdistan Region
}

\author{
Saman M. Mohammed-Amin ${ }^{1 *}$, Bushra M. Jaralla ${ }^{1}$, Kameran M. Ali $^{2}$, Hassan M. Tawfeeq ${ }^{2}$ \\ ${ }^{1}$ College of Medicine, University of Garmian, Kalar, Kurdistan Region, Iraq \\ ${ }^{2}$ Medical Lab Technology Department, Kalar Technical College, Sulaimani Polytechnic University, Kalar, Kurdistan Region, Iraq \\ Received 20 June 2021; revised 01 July 2021; \\ accepted 26 August 2021; available online 01 October 2021 \\ doi: $10.24271 /$ psr.32
}

\begin{abstract}
Bacterial vaginosis (BV) is an inflammatory disease, caused by polymicrobial infection, including pathogenic bacteria which replace the vaginal normal flora and finally this replacement causes manifestations of several physiological and clinical symptoms among women within different ages. BV has become one of the main problems that make woman patients visit gynecological and obstetric consultant hospitals in most country. The present study is designed to determine the causative pathogen and the prevalence of bacterial vaginosis among married women patients in Kalar district. This cross-sectional study was performed from the beginning of March to the mid April-2021 among women who attended Obstetrics and Gynecological governmental hospital and out-patient clinics in Kalar City. Intra vaginal swabs have been collected in sterile Amies transport medium sticks and processed for isolation and identification of bacterial species depending on colony morphology, Gram's stain and microbiological analysis protocols. Then socio-demographic and gynaecologic data were collected by questionnaire. Out of the 108 participant women who suffered from Gynecological diseases, 67(62.03\%) of them exhibited bacterial vaginosis. From the 73 different isolated colonies, 18 bacterial species were identified; coagulase-negative staphylococci (CoNS) were the predominant cause of BV (32.84\%), followed by E. coli (14.93\%), Staphylococcus aureus (13.43\%), Klebsiella pneumonia (8.96) and Micrococcus luteus (7.46\%), while Proteus spp. and some uncommon bacteria display (1.49\%) for each of them. The socio-demographic analysis between positive and negative woman patients revealed that the association between all studied risk factors and BV were statistically significant $(P$ value $<0.05)$ except the age factor which was statistically non-significant meaning that the age was not associated with BV. In addition, the clinical symptom analysis showed that abnormal vaginal discharge, lower back pain, dysmenorrhea and strawberry were significantly associated with BV $(P$ value $<0.05)$, while the rest of other factor did not exhibit statistically significant association.
\end{abstract}

(C) 2021 Production by the University of Garmian. This is an open access article under the LICENSE

https://creativecommons.org/licenses/by-nc/4.0/

Keywords: Bacterial Vaginosis, Prevalence, Women, Risk Factor, Iraq

\section{Introduction}

Generally, at all ages the healthy women have a balanced vaginal ecosystem, this due to the predominance of Lactobacillus species which is considered as a normal flora in this region. The main function of these bacteria is the inhibition of the growth and spread of the rest of other microorganisms via different mechanisms such organic acid production like lactic acid and antimicrobials ingredient including Bacteriocins and hydrogen peroxide). Bacterial vaginosis is basically associated with the diminution of the Lactobacillus species in the vaginal area. Furthermore, the $\mathrm{pH}$ also changes simultaneously after the

* Corresponding author

E-mail address: saman.amin@garmian.edu.krd (Instructor).

Peer-reviewed under the responsibility of the University of Garmian. unbalance that occurred in the vaginal normal flora, which give the chance of growing a variety of other microorganisms especially anaerobic bacteria ${ }^{[1,2,3,4]}$. On the other hand, the alteration of normal flora in the vaginal region with all associated symptoms caused by a polymicrobial assemblage will reflected as bacterial vaginosis ${ }^{[5]}$. Reviewing the presence and prevalence of bacterial vaginosis among all the wide world became the theme and showed widely various in different countries, also it showed different among the same region, as well as, with similar population groups, concerning the range about $8 \%$ to $75 \%{ }^{[6]}$. The clinical condition characterization of bacterial vaginosis include a thin, homogenous, vaginal discharge as malodorous adherent which considered as a noticeable character after intercourse and menses. A fishy odor after adding $10 \%$ potassium hydroxide was noticed when mixed with vaginal fluid. Furthermore, clue cells (vaginal epithelial cells), a few lactobacilli and a little number of 
polymorphonucler leucocyte were found represent the future characters of bacterial vaginosis ${ }^{[7]}$. Previous studies showed the association between prevalence of bacterial vaginosis with different criteria such education level, race, age income, ethnicity, chronic stress as well as gynecologic post-operative infection, pelvic inflammatory disease and both HIV infection and papilloma virus ${ }^{[8,9,10,11,12]}$. The present study was aimed to determine the causative pathogens of bacterial vaginosis and their prevalence among women attending gynecology hospital and outpatient clinics in Kalar City and determining the associated clinical characters among them.

\section{Materials and Methods}

\section{1 Data collection}

This cross-sectional study was conducted from the beginning of March to the mid April-2021 in Obstetrics and Gynecological governmental hospital and out-patient clinics in Kalar City. Socio-demographic and clinical data was obtained from the patients by pretested questionnaire. The questionnaire was comprised of several information concerning several factors including (living place, nationality, age, education, occupation, year of marriage, chronic diseases, previous bacterial vaginosis, vaginal bath, abortion etc. Another part of the questionnaire includes several clinical symptoms such (abnormal vaginal discharge, lower back pain, burning/ itching of genitalia, genital sores, dyspareunia, dysuria, dysmenorrhea and strawberry cervix) ${ }^{[13,14]}$.

\section{2 Sample Collection and Processing}

Amies transport medium was used to collect samples by specialized gynaecologist from the lateral posterior vaginal fornix. Then, the samples were directly transported to the microbiology laboratory in the Garmian university following the standard laboratory procedures. Freshly prepared media (Nutrient agar, MacConkey agar, Blood agar, Chocolate agar and mannitol salt agar) were prepared for isolation and identification of bacteria; the medium was inoculated with the swab and incubated aerobically at $37 \circ \mathrm{C}$ for 24 hours. The plates with no growth were further re-incubated for additional 24 hours before being reported as negative. All isolates were purified by sub-culturing and then Gram stain was applied for differentiation between isolated bacteria under oil immersion (100X). the isolated and purified bacteria was identified according to the bacterial morphology and colony characters. Furthermore, the rest of all unknown isolated bacteria were identified by the VITEK-2 Compact bioMérieux, VITEK-2 cards were inoculated following the manufacturer's instructions and the freshly bacterial culture were used which have less than $18 \mathrm{hrs}$ age $[15,16,17,18]$.

\section{3 Ethical approval:}

Ethical statement was approved by the ethical committee of the college of medicine, University of Garmian. Furthermore, unwritten consent of each of the participant was achieved. Obtained information from the patient will be kept strictly confidential, including all questions in the socio-demographic, reproductive, sexual history, behavioural character and clinical features.

\section{4 Data analysis:}

Collected data were attained for displaying bacterial vaginosis prevalence and microorganisms via descriptive analysis. The categorical variables were presented in frequency and percentages using the IBM statistical Package for Social Sciences version 25 (SPSS - 25). Paired Samples T Test (correlated pairs t-test) were calculated for testing the significance at the $95 \%$ confidences ( $p$ value $<0.05$ ) level of significant and discovering the correlation coefficients (CoR) among the correlated criteria.

\section{Results and Discussion}

Among 108 vaginal swabs, were collected from women patients who attend Obstetrics and Gynecological governmental hospital and out-patient clinics, 67(62.03\%) of them showed positive bacterial vaginosis according to the microbiological analysis as presented in (Figure 1). while the rest 41 (37.97\%) of the samples represented as negative. Depending of the obtained results in our study and compared with the published articles, the bacterial vaginosis occurrence in this area confirmed the prevalence's of it. Our results is in agreement with the principle of prevalence and in higher prevalence rate with that obtained in Nepal by Ranjit et.al., (2018) ${ }^{[19]}$, in India by Modak et.al., (2011) ${ }^{[20]}$ and in Egypt by $\mathrm{Gad}$ et.al., (2014) ${ }^{[21]}$ with a value of $(24.4 \%, 24 \%$ and $33 \%$ respectively). The variation in the obtained results among published articles considered as a normal event, this may due to several characters such geographic distribution, population size, data analysis, behavioural differences and socioeconomic status as described by Ranjit et.al., (2018) ${ }^{[19]}$.

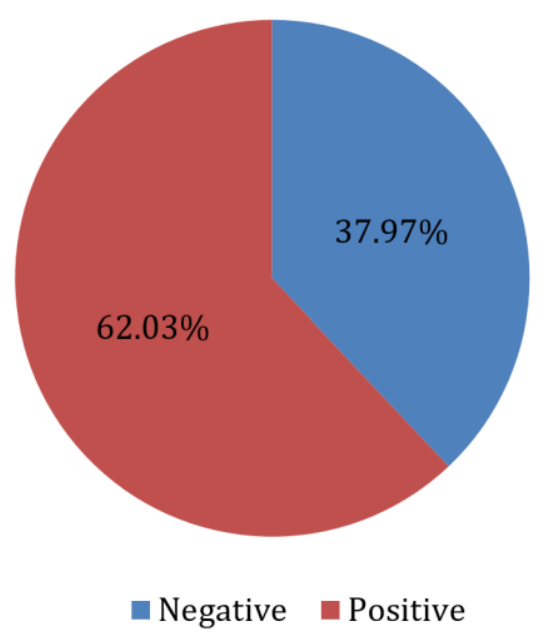

Figure 1: Total presences of bacterial vaginosis among all (108) woman were tested

The bacteria were isolated include both Gram positive and negative bacteria. A total of 73 bacteria species were isolated belong to 18 bacterial species from all 67 positive cases were gave the positive results according to the microbiological investigation. Coagulase-negative staphylococci (CoNS) were the predominant cause of BV 22/67 (32.84\%), followed by E. coli 10/67 (14.93\%), Staphylococcus aureus 9/67 (13.43\%), Klebsiella pneumonia 6/67 (8.96) and Micrococcus luteus 5 $(7.46 \%)$, while Proteus spp. and some uncommon bacteria showed the lowest rate of infection, 1/67 (1.49\%) for each of them as summarized in ( Figure 2). Our results were similar with 
those obtained by all of these published articles Ranjit et al., (2018) ${ }^{[19]}$, Tiyyagura et al., (2012) ${ }^{[22]}$, Maghsoudi et al., (2014) ${ }^{[23]}$, regarding the appearance of the most common Gram positive cocci include both Staphylococcus aureus and Streptococcus agalactiae (12.33\% and $8.22 \%$ respectively). The most common gram negative bacteria were isolated include $E$. coli followed by klebsiella pneumonia and pseudomonas spp as follow (13.70\%, $8.22 \%$ and $2.74 \%$ respectively). Our finding results were contradicted with the studies carried out by Marrazzo et al., (2008) ${ }^{[24]}$ in Seattle, Razzak et al., (2011) ${ }^{[25]}$ in Iraq, and Larsen and Monif (2001) ${ }^{[26]}$ in Omaha and Ranjit et al., (2018) ${ }^{[19]}$, in case of that the most predominant was pseudomonas spp., while in our study $E$. coli became the alternative predominant of the pseudomonas spp. In general, the appearance of the faecal flora within the vaginal discharge may accredited to the unhealthy bowel practices as mentioned by Mumtaz et al., (2008) ${ }^{[27]}$.

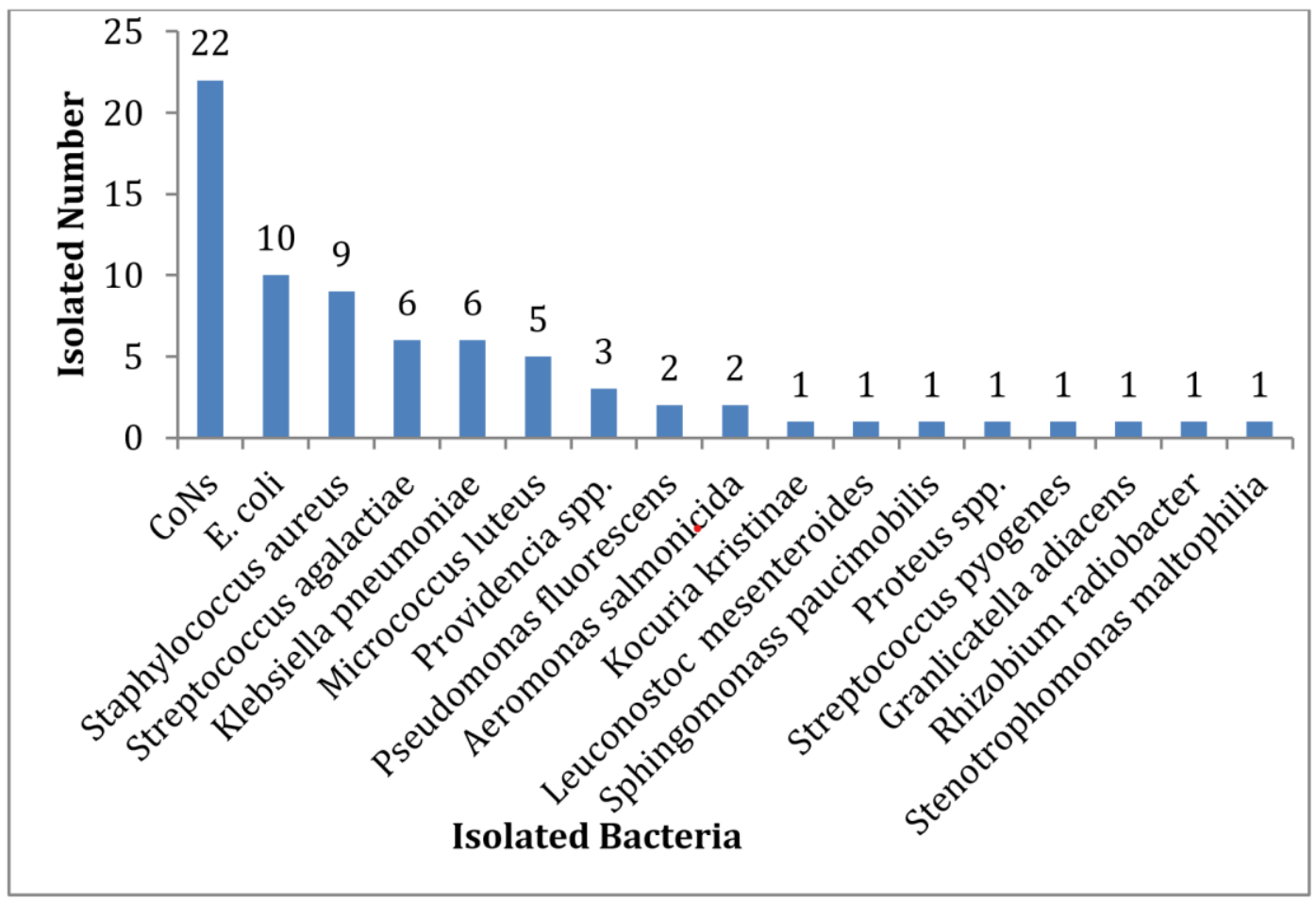

Figure 2: Prevalence of bacterial vaginosis isolates from all positive samples in the study

The results of Socio-demographic characters of the studied woman enlisted according to the presence or absences of bacterial vaginosis with its frequency, $\mathrm{P}$ value and correlation summarized in (Table 1). A total of 108 participated patient woman $62.03 \%$ of them represent positive bacterial vaginosis outcomes. Furthermore, all studied parameters after analyzing the results exhibited significant association with $\mathrm{BV}$ at the $\mathrm{P}$ value $<0.05$ except the age feature which did not show significant association between the positive and negative woman patients. Regarding the correlation coefficient results all characters exhibit the positive correlation except the data associated with age, chronic diseases and years married depicted negatively correlation coefficient with ( $-0.072,-0.104$ and -0.127 respectively). The study of Allsworth et al., (2007) ${ }^{[28]}$ mentioned that the bacterial vaginosis prevalence will increases with age, which measured in line with high prevalence detected with the age range between 21-25 years, our results was disagreement with this outcome. Furthermore, our results were in agreements with that obtained by Bhalla et al., (2007) [29], Bitew et al., (2017) [30], Bhakta et al., (2021) [31], concerning that the presence of the bacterial vaginosis was not significantly associated with age. The results for education was exhibited significantly association among education level $(\mathrm{p}<$ 0.001 ), our result was in agreements with that obtained by Bahram et al., (2009)35 and Nayak et al., (2020) ${ }^{[34]}$, while it was contradicted with that obtained by Xueqiang et al., (2007) ${ }^{[32]}$ and
Bitew et al., (2017) ${ }^{[30]}$. Woman's occupation another feature that exhibit the statistically significant differences $(p<0.001)$, our results was disagreement with that obtained by both Aduloju et al., (2019) ${ }^{[33]}$ and Nayak et al., (2020) ${ }^{[34]}$, in which they achieved there was no significantly association between woman occupation at different skill and jobs.

The next part of Socio-demographic characters' results which related to numerous clinical symptoms with the prevalence of bacterial vaginosis include (abnormal vaginal discharge, burning/ itching genitalia, genital sores, lower back pain, dyspareunia, dysuria, dysmenorrhea, and strawberry cervix) are tabulated in (Table 2). The analyzed data indicated that only abnormal vaginal discharge, lower back pain, dysmenorrhea and strawberry cervix showed the statistically significant association at $(\mathrm{P}$ value $<0.05)$ among all clinically studied characters, while the rest of other characters don't exhibit statistically significant association between the presence and absences of bacterial vaginosis. The results of correlation coefficient between all studied parameters displayed negative correlation except (dysmenorrhea, and strawberry cervix) with $\mathrm{r}^{2}$ positive results $(0.152$ and 0.029 respectively). The obtained results for abnormal vaginal discharge, lower back pain, and strawberry cervix were in agreement with that obtained by Nayak et al., (2020) ${ }^{[34]}$, Bhakta et al., (2021) ${ }^{[31]}$. Concerning the woman reproductive age each of abnormal vaginal discharge, itching of genitalia and burning 
remain the most common problems which related with bacterial vaginosis as documented by Rao et al., (2004) ${ }^{[36]}$ and Valsangkar et al., (2014) ${ }^{[37]}$. The studies of Schwebke et al., (1996) ${ }^{[38]}$ Afolabi et al., (2016) ${ }^{[39]}$; Aduloju et al., (2019) [33] they revealed that most of clinical diagnostic feature somewhat exhibit the good correlation with the gram staining for vaginal discharge in subsequent studies of bacterial vaginosis diagnosis, our outcome data were in agree with overall criteria finding in them previous published articles.

Table 1: Socio-demographic parameters association with the prevalence of bacterial vaginosis demonstrating both positive and negative results with $\mathrm{P}$ value and correlation

\begin{tabular}{|c|c|c|c|c|c|}
\hline \multirow{2}{*}{ Characters } & \multirow{2}{*}{ Frequency } & Bacterial vaginosis & & \multirow{2}{*}{$P$ value } & \multirow{2}{*}{$\mathbf{r}^{2}$} \\
\hline & & Positive 67(62.03\%) & Negative 41 (37.97\% & & \\
\hline \multicolumn{6}{|l|}{ Age } \\
\hline $16-25$ & $31(28.7 \%)$ & $17(15.74 \%)$ & $14(12.96 \%)$ & \multirow{4}{*}{0.460} & \multirow{4}{*}{-0.072} \\
\hline $26-35$ & $36(33.3 \%)$ & $22(25 \%)$ & $14(12.96 \%)$ & & \\
\hline $36-45$ & $31(28.7 \%)$ & $23(21.29 \%)$ & $8(7.40 \%)$ & & \\
\hline$>46$ & $10(9.3 \%)$ & $5(4.62 \%)$ & $5(4.62 \%)$ & & \\
\hline \multicolumn{6}{|l|}{ Nationality } \\
\hline Kurdish & $92(85.2 \%)$ & $59(54.62 \%)$ & $33(30.55 \%)$ & \multirow{3}{*}{0.014} & \multirow{3}{*}{0.055} \\
\hline Arab & $13(12.05 \%)$ & $6(5.55 \%)$ & $7(6.48 \%)$ & & \\
\hline Other & $3(2.8 \%)$ & $2(1.85 \%)$ & $1(0.92 \%)$ & & \\
\hline \multicolumn{6}{|l|}{ Living Place } \\
\hline Urban & $95(88.0 \%)$ & $59(54.62 \%)$ & $36(33.33 \%)$ & \multirow{2}{*}{0.001} & \multirow{2}{*}{0.004} \\
\hline Rural & $13(12.05 \%)$ & $8(7.40 \%)$ & $5(4.62 \%)$ & & \\
\hline \multicolumn{6}{|l|}{ Education } \\
\hline illiterate & $13(12.0 \%)$ & $10(9.25 \%)$ & $3(2.77 \%)$ & \multirow{5}{*}{0.001} & \multirow{5}{*}{0.060} \\
\hline Just literate & $6(5.6 \%)$ & $3(2.77 \%)$ & $3(2.77 \%)$ & & \\
\hline Primary school & $36(33.3 \%)$ & $22(20.37 \%)$ & $14(12.96 \%)$ & & \\
\hline Secondary school & $24(22.2 \%)$ & $14(12.96 \%)$ & $10(9.25 \%)$ & & \\
\hline College & $29(26.9 \%)$ & $18(16.66 \%)$ & $11(10.18 \%)$ & & \\
\hline \multicolumn{6}{|l|}{ Occupation } \\
\hline Unemployed & $2(1.9 \%)$ & $2(1.85 \%)$ & $0(0 \%)$ & \multirow{4}{*}{0.001} & \multirow{4}{*}{0.080} \\
\hline Employed & $15(13.9 \%)$ & $10(9.25 \%)$ & $5(4.62 \%)$ & & \\
\hline Student & $7(6.5 \%)$ & $4(3.70 \%)$ & $3(2.77 \%)$ & & \\
\hline Housewife & $84(77.8 \%)$ & $51(47.22 \%)$ & $33(30.55 \%)$ & & \\
\hline \multicolumn{6}{|l|}{ Years married } \\
\hline 1 to 5 & $33(30.65 \%)$ & $16(14.81 \%)$ & $17(15.74 \%)$ & \multirow{4}{*}{0.001} & \multirow{4}{*}{-0.127} \\
\hline 6 to 10 & $25(23.1 \%)$ & $16(14.81 \%)$ & $9(8.33 \%)$ & & \\
\hline 11 to 15 & $26(24.1 \%)$ & $21(19.44 \%)$ & $5(4.62 \%)$ & & \\
\hline$>15$ & $24(22.2 \%)$ & $14(12.96 \%)$ & $10(9.25 \%)$ & & \\
\hline \multicolumn{6}{|l|}{ Previous BV/GTI } \\
\hline Yes & $83(76.9 \%)$ & $53(49.07 \%)$ & $30(30.55 \%)$ & \multirow[t]{2}{*}{0.015} & \multirow{2}{*}{0.068} \\
\hline No & $25(23.1 \%)$ & $14(12.96 \%)$ & $11(10.18 \%)$ & & \\
\hline \multicolumn{6}{|l|}{ Chronic diseases } \\
\hline Yes & $7(6.5 \%)$ & $3(2.77 \%)$ & $4(3.70 \%)$ & 0.001 & -0.104 \\
\hline
\end{tabular}


Table 2: Various clinical symptoms association with the prevalence of bacterial vaginosis representing both positive and negative results with $\mathrm{P}$ value and correlation

\begin{tabular}{|c|c|c|c|c|c|}
\hline \multirow{2}{*}{ Characters } & \multirow{2}{*}{ Frequency } & \multicolumn{2}{|l|}{ Bacterial vaginosis } & \multirow{2}{*}{$P$ value } & \multirow{2}{*}{$\mathbf{r}^{2}$} \\
\hline & & Positive 67(62.03\%) & Negative 41 (37.97\% & & \\
\hline \multicolumn{6}{|c|}{ Abnormal Vaginal Discharge } \\
\hline yes & $94(87.0 \%)$ & $58(53.70 \%)$ & $36(33.33 \%)$ & \multirow{2}{*}{0.001} & \multirow{2}{*}{-0.018} \\
\hline No & $14(13.0 \%)$ & $9(8.33 \%)$ & $5(4.62 \%)$ & & \\
\hline \multicolumn{6}{|c|}{ Burning \ itchining genitalia } \\
\hline Yes & $72(66.7 \%)$ & $44(40.74 \%)$ & $28(25.92 \%)$ & \multirow[t]{2}{*}{0.486} & \multirow{2}{*}{-0.027} \\
\hline No & $36(33.3 \%)$ & $23(21.29 \%)$ & $13(12.03 \%)$ & & \\
\hline \multicolumn{6}{|l|}{ Genital sores } \\
\hline Yes & $61(56.5 \%)$ & $35(32.40 \%)$ & $26(24.07 \%)$ & \multirow[t]{2}{*}{0.433} & \multirow{2}{*}{-0.109} \\
\hline No & $47(43.5 \%)$ & $32(29.62 \%)$ & $15(13.88 \%)$ & & \\
\hline \multicolumn{6}{|c|}{ Lower back pain } \\
\hline Yes & $92(85.2 \%)$ & $57(52.77 \%)$ & $35(32.40 \%)$ & \multirow{2}{*}{0.001} & \multirow{2}{*}{-0.004} \\
\hline No & $16(14.8 \%)$ & $10(9.25 \%)$ & $6(5.55 \%)$ & & \\
\hline \multicolumn{6}{|l|}{ Dyspareunia } \\
\hline Yes & $62(57.4 \%)$ & $36(33.33 \%)$ & $26(24.07 \%)$ & \multirow[t]{2}{*}{0.510} & \multirow{2}{*}{-0.095} \\
\hline No & $46(42.6 \%)$ & $31(28.70 \%)$ & $15(13.88 \%)$ & & \\
\hline \multicolumn{6}{|l|}{ Dysuria } \\
\hline yes & $59(54.6 \%)$ & $36(33.33 \%)$ & $23(21.29 \%)$ & \multirow[t]{2}{*}{0.278} & \multirow{2}{*}{-0.023} \\
\hline No & $49(45.4 \%)$ & $31(28.70 \%)$ & $18(16.66 \%)$ & & \\
\hline \multicolumn{6}{|c|}{ Dysmenorrhea } \\
\hline Yes & $39(36.1 \%)$ & $28(25.92 \%)$ & $11(10.18 \%)$ & \multirow{2}{*}{0.001} & \multirow{2}{*}{0.151} \\
\hline No & $69(63.9 \%)$ & $39(36.11 \%)$ & $30(30.55 \%)$ & & \\
\hline \multicolumn{6}{|c|}{ Strawberry cervix } \\
\hline Yes & $9(8.3 \%)$ & $6(5.55 \%)$ & $3(2.77 \%)$ & \multirow[t]{2}{*}{0.001} & \multirow{2}{*}{0.029} \\
\hline No & $99(91.7 \%)$ & $61(56.48 \%)$ & $38(35.18 \%)$ & & \\
\hline
\end{tabular}

\section{Conclusion}

This study can be considered as the first article carried out for studying and determining the bacterial vaginosis among woman in Garmian area. Isolating different bacterial species in the obtaining swap sustain highly association with different clinical symptoms were studied by socio-demographic features. So, inclusive healthcare learning for falling the bacterial vaginosis is required. In addition, it is necessary to declare the risk of infection with $\mathrm{BV}$ and the serious consequences, this may lead to the occurrence of occasional cases of disease, in order to evade the spread of BV to the level of prevalence among all ages and marital status.

\section{Acknowledgment}

We thank Dr. Mariwan M. Salah for their help in analyzing the collected data. Our appreciations also for Dr. Isra A, for helping us for collecting samples in the Sheri-Naqeeb Hospital. Our thanks also go to the Head of Biology department in college of Education.

\section{Conflict of interests}

None.

\section{References}

1. Chenicheri, M., Chandramathy, K., Govi, R. and Anitha, P.M., 2017. Prevalence of bacterial vaginosis in cases of preterm labour and its effects on obstetric outcome. $J$ Evid Based Med Healthc, 4(28), pp.1669-1673.

2. Machado, D., Castro, J., Palmeira-de-Oliveira, A., Martinez-de-Oliveira, J. and Cerca, N., 2016. Bacterial vaginosis biofilms: challenges to current therapies and emerging solutions. Frontiers in microbiology, 6, p.1528.

3. Begum, N., Muazzam, N., Shamsuzzaman, S.M., Chowdhury, A., Rashid, A. and Islam, D., 2010. Diagnosis of Bacterial Vaginosis by Acridine Orange Staining and its Comparison to Conventional Methods and Association of Gardnerella vaginalis with Bacterial Vaginosis. Bangladesh Journal of Medical Microbiology, 4(1), pp.37-42.

4. Jesus, R.S., Calil, L.N., Reis, R.D. and Fuentefria, A.M., 2011. Bacterial Vaginosis: Some Aspects for Clinical Practice. Revista Panamericana De Infectologia, 13(4), pp.49-56.

5. Hill, G.B., 1993. The microbiology of bacterial vaginosis. American journal of obstetrics and gynecology, 169(2), pp.450-454.

6. Murta, E.F., Silva, A.O., Silva, E.A. and Adad, S.J., 2005. Frequency of infectious agents for vaginitis in non-and hysterectomized women. Archives of gynecology and obstetrics, 273(3), pp.152-156.

7. Begum, N., Muazzam, N., Shamsuzzaman, S.M., Chowdhury, A., Rashid, A. and Islam, D., 2010. Diagnosis of Bacterial Vaginosis by Acridine Orange Staining and its 
Comparison to Conventional Methods and Association of Gardnerella vaginalis with Bacterial Vaginosis. Bangladesh Journal of Medical Microbiology, 4(1), pp.37-42.

8. Culhane, J.F., Rauh, V., McCollum, K.F., Elo, I.T. and Hogan, V., 2002. Exposure to chronic stress and ethnic differences in rates of bacterial vaginosis among pregnant women. American journal of obstetrics and gynecology, 187(5), pp.1272-1276.

9. Ness, R.B., Kip, K.E., Hillier, S.L., Soper, D.E., Stamm, C.A., Sweet, R.L., Rice, P. and Richter, H.E., 2005. A cluster analysis of bacterial vaginosis-associated microflora and pelvic inflammatory disease. American journal of epidemiology, 162(6), pp.585590 .

10. Watts, D.H., Fazarri, M., Minkoff, H., Hillier, S.L., Sha, B., Glesby, M., Levine, A.M., Burk, R., Palefsky, J.M., Moxley, M. and Ahdieh-Grant, L., 2005. Effects of bacterial vaginosis and other genital infections on the natural history of human papillomavirus infection in HIV-1-infected and high-risk HIV-1-uninfected women. The Journal of infectious diseases, 191(7), pp.1129-1139.

11. Allsworth, J.E. and Peipert, J.F., 2007. Prevalence of bacterial vaginosis: 2001-2004 national health and nutrition examination survey data. Obstetrics \& Gynecology, 109(1), pp.114-120.

12. Cohen, S., Kamarck, T. and Mermelstein, R., 1983. A Global Measure of Perceived Stress, Journal of Health and Social Behavior, Vol. 24.

13. Aduloju, O.P., Akintayo, A.A. and Aduloju, T., 2019. Prevalence of bacterial vaginosis in pregnancy in a tertiary health institution, south western Nigeria. The Pan African Medical Journal, 33.

14. Amsel R, Totten PA, Spiegel CA, Chen KC, Eschenbach D, Holmes KK. Nonspecific vaginitis. Diagnostic criteria and microbial and epidemiologic associations. Am J Med 1983; 74(1): 14- 22

15. Nugent, R.P., Krohn, M.A. and Hillier, S.L., 1991. Reliability of diagnosing bacterial vaginosis is improved by a standardized method of gram stain interpretation. Journal of clinical microbiology, 29(2), pp.297-301.

16. Ranjit, E., Raghubanshi, B.R., Maskey, S. and Parajuli, P., 2018. Prevalence of bacterial vaginosis and its association with risk factors among nonpregnant women: A hospital based study. International journal of microbiology, 2018.

17. Spiegel CA, Amsel R, Holmes KK. Diagnosis of bacterial vaginosis by direct Gram staining of vaginal fluid. J Clin Microbiol. 1983; 18(1): 170-177. PubMed | Google Scholar.

18. Romero-Gómez, M.P., Gómez-Gil, R., Paño-Pardo, J.R. and Mingorance, J., 2012. Identification and susceptibility testing of microorganism by direct inoculation from positive blood culture bottles by combining MALDI-TOF and Vitek-2 Compact is rapid and effective. Journal of Infection, 65(6), pp.513-520.

19. Ranjit, E., Raghubanshi, B.R., Maskey, S. and Parajuli, P., 2018. Prevalence of bacterial vaginosis and its association with risk factors among nonpregnant women: A hospital based study. International journal of microbiology, 2018.

20. Modak, T., Arora, P., Agnes, C., Ray, R., Goswami, S., Ghosh, P. and Das, N.K., 2011. Diagnosis of bacterial vaginosis in cases of abnormal vaginal discharge: comparison of clinical and microbiological criteria. The Journal of Infection in Developing Countries, 5(05), pp.353-360.

21. Gad', G.F., El-Adawy, A.R., Mohammed, M.S., Ahmed, A.F. and Mohamed ${ }^{1}$, H.A., 2014. Evaluation of different diagnostic methods of bacterial vaginosis. IOSR Journal of Dental and Medical Sciences, 13(1), pp. 15-23

22. Tiyyagura, S., Taranikanti, M., Ala, S. and Mathur, D.R., 2012. Bacterial vaginosis in indian women in the reproductive age group. International Journal of Biomedical Research, 3(8), p.371.

23. Maghsoudi, R., Setorki, M. and Doudi, M., 2014. Prevalence of the genital tract bacterial infections after vaginal reconstructive surgery. Pakistan Journal of Biological Sciences, 17(9), pp.1058-1063.

24. Marrazzo, J.M., Thomas, K.K., Fiedler, T.L., Ringwood, K. and Fredricks, D.N., 2008. Relationship of specific vaginal bacteria and bacterial vaginosis treatment failure in women who have sex with women. Annals of internal medicine, 149(1), pp.20-28.
25. Razzak, M.S.A., Al-Charrakh, A.H. and Al-Greitty, B.H., 2011. Relationship between lactobacilli and opportunistic bacterial pathogens associated with vaginitis. North American Journal of Medical Sciences, 3(4), p.185.

26. Larsen, B. and Monif, G.R., 2001. Understanding the bacterial flora of the female genital tract. Clinical Infectious Diseases, 32(4), pp.e69-e77.

27. Mumtaz, S., Ahmad, M., Aftab, I., Akhtar, N., ul Hassan, M. and Hamid, A., 2008. Aerobic vaginal pathogens and their sensitivity pattern.J Ayub Med Coll Abbottabad, 20(1), pp.113-117.

28. Allsworth, J.E. and Peipert, J.F., 2007. Prevalence of bacterial vaginosis: 2001-2004 national health and nutrition examination survey data. Obstetrics \& Gynecology, 109(1), pp.114-120.

29. Bhalla, P., Chawla, R., Garg, S., Singh, M.M., Raina, U., Bhalla, R. and Sodhani, P., 2007. Prevalence of bacterial vaginosis among women in Delhi, India. Indian Journal of Medical Research, 125(2), p.167.

30. Bitew, A., Abebaw, Y., Bekele, D. and Mihret, A., 2017. Prevalence of bacterial vaginosis and associated risk factors among women complaining of genital tract infection. International Journal of Microbiology, 2017.

31. Bhakta, V., Aslam, S. and Aljaghwani, A., 2021. Bacterial vaginosis in pregnancy: prevalence and outcomes in a tertiary care hospital. African Journal of Reproductive Health, 25(1), pp.49-55.

32. Xueqiang, F., Yingzhi, Z., Yanfang, Y., Yutao, D. and Huiqing, L., 2007. Prevalence and risk factors of trichomoniasis, bacterial vaginosis, and candidiasis for married women of child-bearing age in rural Shandong. Japanese journal of infectious diseases, 60(5), p.257.

33. Aduloju, O.P., Akintayo, A.A. and Aduloju, T., 2019. Prevalence of bacterial vaginosis in pregnancy in a tertiary health institution, south western Nigeria. The Pan African Medical Journal, 33.

34. Nayak, M., Purohit, P., Debta, A., Sinha, S., Patel, S., Patel, O., Das, P. and Sahoo, S., 2020. Prevalence of bacterial vaginosis in postmenopausal women in the state of Odisha, India.

35. Bahram, A., Hamid, B. and Zohre, T., 2009. Prevalence of bacterial vaginosis and impact of genital hygiene practices in non-pregnant women in Zanjan, Iran. Oman medical journal, 24(4), p.288.

36. Rao, P.S., Devi, S., Shriyan, A., Rajaram, M. and Jagdishchandra, K., 2004. Diagnosis of bacterial vaginosis in a rural setup: Comparison of clinical algorithm, smear scoring and culture by semiquantitative technique. Indian journal of medical microbiology, 22(1), p.47.

37. Valsangkar, S., Selvaraju, D., Rameswarapu, R. and Kamutapu, S., 2014. Impairment of quality of life in symptomatic reproductive tract infection and sexually transmitted infection. Journal of reproduction \& infertility, 15(2), p.87.

38. Schwebke, J.R., Hillier, S.L., Sobel, J.D., McGREGOR, J.A. and Sweet, R.L., 1996. Validity of the vaginal gram stain for the diagnosis of bacterial vaginosis. Obstetrics \& gynecology, 88(4), pp.573-576.

39. Afolabi, B.B., Moses, O.E. and Oduyebo, O.O., 2016, January. Bacterial vaginosis and pregnancy outcome in Lagos, Nigeria. In Open forum infectious diseases (Vol. 3 , No. 1, p. ofw030). Oxford University Press. 